\title{
Fatores determinantes no processo de decomposição em florestas do Estado de São Paulo
}

\author{
Camila de Toledo Castanho
}

\section{Resumo}

A atividade de decomposição constitui-se em importante indicador do padrão funcional dos ecossistemas, pois controla processos básicos relacionados à disponibilidade de nutrientes e produtividade. Salienta-se a importância das características climáticas, edáficas, da qualidade da serapilheira e da fauna do solo como determinantes no processo de decomposição. No entanto, a importância de cada um destes fatores varia em escalas de tempo e espaço. O objetivo deste trabalho foi avaliar a importância de alguns fatores determinantes na decomposição em trechos representativos dos principais ecossistemas florestais do Estado de São Paulo. Para tanto foram conduzidos dois experimentos independentes.

O primeiro, aqui denominado Experimento Exóticas, examinou os efeitos do tipo florestal e da fauna do solo sobre a decomposição de folhas de uma espécie exótica (Laurus nobilis L.) em duas florestas úmidas (Floresta de Restinga do Parque Estadual da Ilha do Cardoso e Floresta Atlântica de Encosta do Parque Estadual Carlos Botelho) e uma floresta estacional (Floresta Estacional Semidecidual da Estação Ecológica de Caetetus). Os efeitos destes fatores foram testados em duas situações: acima e abaixo da superfície simulando então o ambiente de decomposição de folhas e raízes respectivamente. O tipo florestal apresenta efeito superior à fauna acima da superfície, enquanto abaixo apenas o efeito da fauna é significativo. Esses resultados indicam que a hierarquia dos fatores determinantes na decomposição difere para folhas e raízes. Se por um lado a decomposição de folhas é muito mais susceptível às mudanças climáticas do que a de raízes, por outro, alterações na comunidade afetam a decomposição em ambas as condições. Acima da superfície, a fauna apresentou efeito significativo apenas na Floresta Atlântica de Encosta, sendo essencial na diferenciação das duas florestas úmidas. Abaixo da superfície e na ausência da fauna, a porcentagem de massa remanescente foi muito similar nas três florestas. No entanto, diferenças entre as florestas, na presença da fauna, tornam-se aparentes sugerindo que há contribuição específica da fauna na decomposição de raízes destas florestas. A Floresta de Restinga apresentou o efeito mais pronunciado da fauna abaixo do solo. Esses resultados indicam que a fauna é um fator de notável importância na determinação da decomposição de raízes, particularmente em florestas tropicais úmidas arenosas.
Outro experimento, aqui denominado Experimento Nativas, foi desenvolvido para avaliar o efeito do substrato e da formação florestal na decomposição de folhas de quatro espécies nativas em trechos das quatro principais formações florestais do Estado de São Paulo. Para tanto, o experimento foi desenvolvido nos três trechos florestais do experimento Exóticas incluindo ainda o Cerradão da Estação Ecológica de Assis. Foi escolhida uma espécie de árvore, em cada um dos tipos florestais, para que suas folhas fossem usadas como substrato nas bolsas de serapilheira. Tipo florestal e substrato demonstraram efeito significativo sobre a quantidade de massa remanescente ao longo do experimento. A maior parte das espécies sofreu maiores perdas na Floresta Atlântica, seguida da Floresta de Restinga, Floresta Estacional e Cerradão. Esses resultados sugerem que o total de precipitação associado a sua distribuição são importantes determinantes no processo de decomposição, de forma que as duas florestas mais úmidas apresentam, em média, taxas de decomposição duas vezes maiores do que as duas florestas estacionais. As demais diferenças encontradas entre as formações florestais devem ser explicadas por características edáficas e bióticas. Em relação ao efeito das espécies, observaram-se as maiores perda de massa em Esenbeckia leiocarpa Engl., seguida de Copaifera langsdorfii Desf., Guapira opposita Vell. e Calophyllum brasiliensis Camb.. Os parâmetros químicos só mostram correlação negativa significativa com as taxas de decomposição quando $G$. opposita é excluída da análise. Neste caso a porcentagem de lignina foi o parâmetro que apresentou melhor correlação $\left(\mathrm{r}^{2}=\right.$ 0,59). Apesar dos padrões gerais apresentados acima, a interação entre tipo florestal e substrato evidencia algumas variações, que se relacionam principalmente ao aumento relativo na perda de massa de $C$. langsdorfii em sua área de origem, o Cerradão. Quando comparadas as taxas de decomposição (k) encontradas na Floresta Estacional e no Cerradão, $C$. langsdorfii apresenta decaimento $40 \%$ maior no Cerradão, enquanto as demais espécies apresentam, em média, taxas 28\% menores no Cerradão do que na Estacional. Esses resultados sugerem estreita correlação entre a comunidade decompositora e a serapilheira local.

O estudo do processo de decomposição, reconhecendo seus fatores determinantes e a variação na hierarquia desses fatores em diferentes condições ambientais, como apresentado nesse trabalho, é de fundamental importância, não só para o entendimento dos 
ecossistemas florestais de São Paulo, mas para o

planejamento de atividades de manejo, restauração e conservação.

Palavras-chave: serapilheira de folhas, bolsas de serapilheira, qualidade da serapilheira, controle do clima sobre a decomposição, fauna do solo 